\title{
A Review of Policies, Acts and Initiatives in Rice Innovation System in Nigeria
}

\author{
Emodi, I. A and M.C. Madukwe \\ Department of Agricultural Extension \\ University of Nigeria, Nsukka
}

\begin{abstract}
A review of rice policies, acts and initiatives in Nigeria is presented under pre-ban period (1971-1985); ban period (1986-1995); and post ban period (1995-date). The key actors and the elements of acts and initiatives in the rice innovation systems were identified and presented. The growth in rice demand as a preferred staple has been so strong that production intensification and higher yields per ha was not sufficient to fill the gap and meet rice demand. In spite of successes recorded in rice production, there were a lot of gaps in the system. The policies, acts and initiatives failed to recognize the problems of the stakeholders because they were detached and foreign to the tradition and cultural practices of the stakeholders. The country's policy on rice has been inconsistent and has oscillated between import tariffs and import restrictions including outright ban. Pressure from international financial organizations, such as the World Bank, World Trade Organization, and International Monetary Fund (IMF) helped in introducing distortions in the policies. Efforts by all stakeholders, the desirable political will by government and sound agricultural rice policy are essential to ensure that necessary conditions exist in meeting rice production.
\end{abstract}

Key word: rice policy, rice innovation system.

\section{INTRODUCTION}

Nigeria is currently the highest rice producer in West Africa, producing an average of 3.2 million tons of paddy rice or 2.0 million tons of milled rice (Daramola, 2005). It is also the largest consuming nation in the region, with the growing demand amounting to 4.1 million tons of rice in 2002 , with only about half of that demand met by domestic production (USDA FAS, 2003). Nigeria imported 1.9 million tons of rice in 2002 valued at approximately 500 million USA dollars (USDA FAS, 2003).

Rice production requires an integrated quality management along the entire commodity chain from rice production, through processing and marketing. Erenstein et al (2003) observed that different actors are involved in each stage in rice production. The Public Sector (government, universities, research institutes, extension agencies) and Private sector (rice farmers, non-governmental organizations-NGOs, processors, millers, marketers, distributors, input and service providers) are involved in rice production. These actors are key players in rice innovation and are important in the development of behavioral patterns that make organizations and policies sensitive to stakeholders (Ashley and Carney, 1999). Rice production requires a radical shift from 
traditional thinking and approaches to complementary technologies such as participatory approaches, decision support, post-harvest technologies, especially rice innovation (WARDA, 2005). Innovation involves using knowledge to find new ways to create and bring about change. It may require the creation of new knowledge but inspired application of knowledge to create additional value (Evans, 2004). Therefore team work is the core of innovation. Innovation system embraces not only the science suppliers but also the totality and interaction of actors involved in innovation (Hall and Dijkman2006). It extends beyond the creation of knowledge to encompass the factors affecting knowledge in useful ways. Biggs and Matsaert (2004), observed that an effective innovation system facilitates flow of information and mutual partnerships between actors.

\section{Rice production}

Table 1 revealed that there were fluctuations in rice production. The decline in domestic rice production cannot all be blamed on increasing rice imports. The Nigerian government has actively interfered with the rice economy over the last thirty years. The country's policy on rice has been inconsistent and has oscillated between import tariffs and import restrictions including outright ban. For instance, there was subsidized provision of inputs and finance for production, but none of these measures halted the long term end to import dependency (Akande, 2002). According to Coulter and Havrland (2005), seeking to eliminate imports over a short-time span is totally unrealistic with consumption outstripping production. Despite several measures to promote sufficient rice production, Nigeria still imports around 2 million metric tons of rice a year. According to Tollens (2006), the growth in rice demand as a preferred staple, is so strong that production intensification and higher yields per ha has not been sufficient to fill the gap and meet rice demand. Intensification or a rapid increase in the area under rice (irrigated and rain fed) are necessary.

TABLE 1: 1961 - 2006 Rice Production Figures in Nigeria

\begin{tabular}{ccccccc}
\hline Period & $\begin{array}{c}\text { Area } \\
\text { (hectares) }\end{array}$ & $\begin{array}{c}\text { Unpolished } \\
\text { rice } \\
\text { quantity }\end{array}$ & $\begin{array}{c}\text { Yield } \\
\text { (Tonnes/ } \\
\text { Hectares }\end{array}$ & $\begin{array}{c}\text { Domestic } \\
\text { Out } \\
\text { Milled In } \\
\text { tonnes }\end{array}$ & $\begin{array}{c}\text { Rice } \\
\text { imports } \\
\text { (Tonnes) }\end{array}$ & $\begin{array}{c}\text { self- } \\
\text { sufficiency }\end{array}$ \\
\hline 1961 & 149,000 & 133,000 & 0.893 & 88,711 & 1,100 & 98.78 \\
1966 & 160,000 & 199,000 & 1.244 & 132,733 & 1,75 & 99.05 \\
1971 & 304,000 & 388,000 & 1.276 & 258,796 & 255 & 99.90 \\
1976 & 172,000 & 218,000 & 1.267 & 145,406 & 45,377 & 76.22 \\
1981 & 600,000 & $1,241,000$ & 2.068 & 656,799 & 656,799 & 55.76 \\
1986 & 700,000 & $1,416,322$ & 2.023 & 944,687 & 320,000 & 74.70 \\
1991 & $1,652,000$ & $3,226,000$ & 1.953 & $2,151,742$ & 296,000 & 87.91 \\
1996 & $1,815,770$ & $2,909,230$ & 1.602 & $2,082,374$ & 345,500 & 85.77 \\
2001 & $1,770,000$ & N.R & N.R & $2,752,000$ & N.R & N.R \\
2006 & N.R & N.R & N.R & $4,300,000$ & N.R & N.R \\
\hline
\end{tabular}

Source: Summary from PCU, FMARD, Nigeria; FAOSTAT Database.

${ }^{*} N R-$ No Record 
Despite the fact that rice contributes significant amount in the food requirements of the population, production seemed far below the national requirements. Rice production in Nigeria rose from 2.7 million metric tones in 2001, to 4.3 million metric tones in 2006. Despite the rise in domestic production, the demand/consumption of rice far exceeds local production, precipitating an increase in the rice importation bill to as high as 160 million USA dollars in 2003 (FAO, 2003). The importation of milled rice was used to bridge the gap between the domestic demand and supply. Nigeria's total land mass (1.7 million hectares) cropped to rice is not fully developed because of lack of appropriate technology (Godwin, Lancon and Erenstein, 2001).

In the face of changing environmental and economic realities, innovation system in agriculture, constitutes the cornerstone in efforts to develop rice production and improve the livelihood strategies of framers in Sub Saharan Africa (Sanginga et al, 2004). Sound agricultural rice policy is essential to ensure that necessary conditions exist in meeting rice production. What policies, acts and initiative exist within the rice innovation system in Nigeria? Who are the key actors in rice innovation system?

\section{Purpose of the study:}

- Review policy, acts and initiatives in rice innovation system;

- Identify and examine the key actors in rice production;

- Identify the gaps and constraints that exist in rice policies.

\section{RESULT AND DISCUSSION}

\section{Policies, acts and initiatives}

From historical perspective, rice policies and acts in Nigeria can be discussed under three periods (Akande, 2002). These are:

Pre-ban period, (1971-1985). This can be classified into pre-crisis (1971-1980) and the crisis period (1981-1985). The Pre-Crisis period was largely characterized by liberal policies (agricultural policies, programs, projects and institutions) on rice imports. Ad-hoc policies were put in place during times of interim shortages. It corresponded to the launching of various programmes and projects aiming at developing rice production. During the crisis period, more stringent policies (Input Supply and Distribution Policy, Agricultural Input Subsidy Policy, Water Resources and Irrigation Policy, Agricultural Cooperatives Policy) were put in place, government policies had artificially lowered domestic rice and fertilizer prices relative to the world price level, through massive importation of rice resulting in low price of locally produced rice. Government was involved in rice importation, distribution, and its marketing with non transfer of actual costs to consumers. There was protection of elite consumers at the expense of farmers, leading to depressed farm gate prices. This eroded the competitiveness of locally produced rice and served as major disincentive to rice framers.

Ban period (1986-1995): The ban placed on rice import was reinforced by the introduction of Structural Adjustment Programme (SAP) in 1986. Under SAP, various trade policies (tariff, import restrictions, and outright ban on rice import at various times) were put in place. It was illegal to import rice into the country, though 
importation of the commodity through the country's porous borders thrived during this period.

Post-ban period (1995- date): During this period restrictions on rice importation were lifted, with more liberal trade policy put in place. The decline in domestic rice production cannot all be blamed on increasing rice imports. The country's policy on rice has also been inconsistent and has oscillated between import tariffs and import restrictions including outright ban. A number of reasons led to the lifting of the ban. There was extended pressure from the international financial organizations, such as the World Bank, World Trade Organization, and the International Monetary Fund (IMF) who argued that the ban on rice was not in consonance with the liberalization position of the government. On the domestic scene, the government failed in the implementation of the ban on the commodity. This is evidence by the major markets in Nigeria flooded with imported rice despite restrictions. There was also pressure on the government by those who had vested interest in rice importation and the urban elites who had a preference for the consumption of imported rice (Ladebo, 1999).

\section{Programmes and agencies in rice innovation system in Nigeria}

Attention was not focused on rice during the pre-colonial colonial period. During this period, focus was rather on export crops such as cocoa, groundnut, rubber and palm produce; supported through pricing and marketing board policies. Thus rice and other food crops were left to develop at there own pace with no incentives, in the hands of the peasant farmers (Akpokodge, Lancon, Erenstein, 2001). To attain modest strides in rice production, some actions were taken by some key actors with collaboration of national and international organizations. The following are the summary of the major institutions engaged in rice production with their dates of establishments and mandates:

\section{National programmes and agencies}

1970 - Federal Rice Research Station (FRRS) was established in Nigeria to research into the development of improved varieties of grains. The objectives were achieved through introduction and adaptation by the rice farmers.

1972 - National Accelerated Food production Program (NAFPP) was funded with the mandate to effectively design, test and transfer technology package for production of Rice, maize, sorghum, millet and wheat.

1974 - National Cereals Research Institute (NCRI) lunched to carry out research on high yielding rice varieties for farmers, on-farm adaptive research, seed multiplication and training of extension staff.

1976 - The Operation Feed the Nation (OFN) was established for self-sufficiency in domestic food supply. There was introduction of land use subsidy Decree, seed and fertilizer supply, credit and mechanization in agriculture.

1978 - Abakaliki Rice Project was established for rice production and processing

1987 - Agricultural Development Project (ADP) is the main link between research and farmers. It has been a channel through which government policies on rice production were implemented.

1988 - Nigerian Agricultural and Cooperative Bank (NACB) was established for special credit schemes to boost rice production and other activities/crops (maize, sorghum). 
1999 - The Presidential Rice Initiative was launched to address the widening demand supply gap and attain self-sufficiency in rice production.

International programmes and agencies:

1971 - West Africa Rice Development Association (WARDA) was established to increase the sustainable productivity of intensified rice based cropping systems in a manner that improves the welfare of resource-poor farm families, conserves and enhances their natural resource base.

1985 - International Network for the Genetic Evaluation of Rice (INGER-Africa), addresses the needs of National Agricultural Research Station by distribution of rice nurseries tailored to meet the needs of national programmes.

1986 - Green River Project is an outfit established by Nigerian Agip Oil Company (NAOC). It launched Burma rice project for the traits, evaluation and identification of the best rice production and management techniques.

1988 -Germplasm Collection and Conservation- is for the conservation of rice germplasm for the production of improved rice varieties which are resistant to viruses, pests and diseases.

1998 -PropCom is a market driven intervention programme. They facilitate initiatives for production of quality local rice in sufficient quantities. It is to compete with imported rice and benefit the poor stakeholders.

2000 - Shell Petroleum Development Company (SPDC) resumed an experimental basis for the distribution of improved varieties of rice to farmers.

2000 - Multinational New Rice for Africa (NERICA) Rice Dissemination Project (MNRDP) was established for technology transfer, product support, capacity building and project coordination.

2001 - The Ibom Rice Project was established for practical training of local farmers on modern farming technique in rice production

\section{Gaps in rice policies, acts and initiatives in Nigeria}

Imported policy concepts: Most policies relating to rice failed to recognize the problems of the stakeholders. They are detached and foreign to the tradition and cultural practices of the stakeholders. The situation existed because the Nigerian government failed to provide the necessary financial support to rice innovation system. The non-governmental Organizations (NGOs), (Consultative Group on International Agricultural Research (CGIAR), International Rice Research Institute (IRRI), National agricultural research Station (NARS), Green River Project (GRP), Shell Petroleum development Company(SPDC)), self-funded by their parent body or foreign donors controlled the mandates and pace of rice performance.

Lack of incentives: There was lack of economic incentives for wide and massive adoption, due to

- poor technology transfer and delivery system, especially for seed; and 
- inappropriate agricultural polices: though polices are needed to encourage competiveness of domestic rice production against heavily subscribed imports, but overriding problem is the decline in the regions self- sufficiency in rice production and increasing dependency on imports (FAO, 2004).

\section{Weak provision of Market Information Services}

Lack of market information creates unequal playing fields between middlemen and farmers. This negatively affects the terms of trade for small holder farmers and raises market transaction costs which lead to poor integration of markets across space and time. Market failure is the major reason for both the low productivity and uncompetitive market for domestic rice. When markets fail, capacity of smallholder farmers to use available prospective technologies is undermined.

\section{Absence of coordinated infrastructure}

Existing initiative did not coordinate the timely and effective provision of the necessary infrastructure for rice innovation system. Some of the major rice producing areas had poor access road. Again some areas were constrained by inadequate and inappropriate processing equipment, especially at the farm or village level. The inability to provide and use improved technologies in rice processing has led to the production of poor quality of domestic rice that is not competitively marketable.

\section{Poor provision for learning and technological capacity building}

Overtime, the succeeding initiatives showed poor provisions for the development of the needed capability to drive the rice innovation system. Similarly, they were evidence of poor learning as some of the weaknesses were transferred from preceding initiatives. There was lack of solid support for science to address most of the problems facing rice production such as drought, soil fertility depletion, diseases and pests.

\section{CONCLUSION}

To improve quality of domestic rice, innovations are needed that will make producers more responsive to end-user requirements and attach much more importance to rice processing (milling, and identity preservation). There is great potential in improved varieties-resistant to pests, and small doses of organic and inorganic fertilizers for integrated soil fertility management. Unless farmers get access to seeds, chemical fertilizers and other complementary inputs to improve their yields, rice farmers cannot produce sufficient rice to feed the teeming population.

The general policy and rural infrastructure environment needs to be improved to help farmers become competitive in accessing markets and raising their incomes. For this to happen, there is need to: set up credit guarantee facility within an organized rice market; facilitate private companies to be linked up with rural agrodealers; and, be part of an innovative private-public-community partnership. There must be the needed political will by government to adequately fund research based institutions to address identified problems relating to drought, soil fertility depletion, diseases and pests. Also the required human capacity which is limited should be further improved upon. 
There has been lack of right policy to take advantage of identified gaps in the domestic rice production. The inability to reach self sufficiency in rice production is a result of several constraints in the rice industry which require urgent redress to stem the trend of over-reliance on imports and to satisfy the increase demand in bridging the gap in rice production. Conscientious efforts by all stake holders, the desirable political will by government and sound agricultural rice policy is essential to ensure that necessary conditions exist in meeting rice production.

\section{Reference}

Akpokodje, G; Lancon, F; Olaf, E. (2001). The Nigerian Rice Economy in a Competitive World. Constraints, Opportunities and Strategic Choices. WARDA Bouake, Cote

d'Ivoire.www.usaid.gov/ng/downloads/markets/rice/report/of/the/final/technical/ workshop.pdf -

Ashley, C. and Carney, D (1999). Holistic Approaches to Poverty Reduction, where does agricultural research fit in? Paper Submitted to the International Seminar on "Assessing the Impact of agricultural research on Poverty Alleviation: San Jose, Costa Rica. International Centre for Tropical Agriculture (CIAT).

Biggs,S; and Matsaert, H. (2003). Strengthening Poverty Reduction Programmes using an Actor Oriented Approach: Examples from National Resources Innovation Systems. ODI AgREN Network Papers series 134. London.

Coulter, J. and Bohumil H. (2005), monitoring of project 3.2 (project5): policy Environment and Rice market Development at WARDA, ECART-NATURA, Monitoring of CGTAR-Projects co-founded by the European commission in 2004

Daramola, Biyi (2005). Government policies and competitiveness of Nigerian rice economy. Paper presented at the workshop on rice policy and food security in Sub-Saharan Africa. WARDA Cotonou, Republic of Benin.

Erenstein, O; Lancon, F; Akande, S.O; Titilola, S.O. Akpokodje G; and Ogundele, O.O. (2003). Rice production in Nigeria: A survey project report - The Nigerian Rice Economy in a competitive world. Constraints, opportunities and strategies choices. Abidjan WARDA.

Evans,H. (2004). What drives America`s great innovations? (ed) Aalos, C.S.(2005). A Century of Rice Innovations. Discussion Paper Series No. 200512.http;//www.pids.gov.ph

Food and Agriculture Organisation, FAOSTAT (2003). FAO statistical database. Available online at http://apps.fao.org

Food and Agriculture Organisation, (2004). The State of Food Insecurity in the world. Rome. www.fao.org.

Federal Ministry of Agriculture and Rural Development (FMARD, 2001). New Agricultural Policy. Abuja, Nigeria. 
Hall, A and Dijkman, J. (2006). Capacity development for Agricultural biotechnology in developing Countries: Concepts, case studies and Operational challenges of a systems perspective. N2006-003.United Nations University-Maastricht economic and social research and training centre on Innovation and Technology). http://www.merit.unu.edu

IRRI (2001) International Rice Research Institute. Delivery for impact. The dissemination of rice-related knowledge and technology. Los Barlos, Philippines.

Ladebo, O.J (1999). "Determinants of Adoption of New Technology among rice Farmers in Ifo Local Government of Ogun State, Nigeria."ACTA Universities Agriculturae et silviculturae Mendelinae Brunensis, Vol. 48.

Odera, J. (2004). Lessons Learnt on Sustainable Forest Management in Africa. National Museums of Kenya. Nairobi, Kenya

Sanginga, P.C.; R. Best; C. Chitsike; R. Delve; S. Kaaria, R. Kirkby (2004). Enabling rural innovation in Africa. An approach for integrating farmer participatory research and market orientations for building the assets of rural poor. Uganda Journal of Agricultural Sciences. 9:942-57.

USDAFAS, (2003).United States Department of Agriculture and Foreign Agricultural Service, Nigeria Product brief rice. Gain report N13026. USDAFAS: Mistowa. Org/files/corpao/ 2006/CRPAO320064/RIFAN/ Nigeria. Pdf.

West Africa Rice development Center, (WARDA, 2005).

http://www.warda.org/newsletter/no\%208/charting.htm.number 8 